\title{
Politics and Educational Leadership in Nigerian Schools: Issues and Challenges
}

\author{
Njideka Gloria Ikegbusi¹, Uchenna C. Chigbo-Okeke², Melody Ndidi Modebelu ${ }^{3}$ \\ ${ }^{1}$ Department of Educational Management and Policy, Nnamdi Azikiwe University, Awka, Nigeria \\ ${ }^{2}$ Department of Educational Management and Planning, Imo State University, Owerri, Nigeria \\ ${ }^{3}$ Department of Educational Management, Michael Okpara University of Agriculture, Umudike, Nigeria \\ Email: glorimyi72@gmail.com, meloodyne@gmail.com
}

Received 16 May 2016; accepted 22 July 2016; published 26 July 2016

Copyright (C) 2016 by authors and OALib.

This work is licensed under the Creative Commons Attribution International License (CC BY).

http://creativecommons.org/licenses/by/4.0/

(c) (i) Open Access

\begin{abstract}
This paper intended to provide a brief overview of the issues and challenges in the educational leadership in Nigerian schools and the political involvement in the managerial structure. Tracing down the history of education during and after the colonial era, were indications of types of schools within the stated period, whether public or mission schools, and the political involvement in the management, leadership and students' admission. Many concerned citizens have written on the educational system and attributed its deploying conditions to poor implementation of curriculum, inadequate funding and poor monitoring or supervision. The paper concludes that the politics in the educational sector was based mostly on quota system and godfathers, which adversely affect educational leadership of the country. Based on these it was recommended among others that politicians should allow the education authorities to select leaders for schools with a stated standard. Again, experts should be in the leadership positions of schools and should be made to be autonomous.
\end{abstract}

\section{Keywords}

Politics, Education, Educational Leadership, Nigerian Schools, Issues, Challenges

Subject Areas: Education

\section{Introduction}

The writer wishes to say that politics should be known first, as to know its involvement in the educational sector. Politics according to [1] means activities that involve getting and using power in public life, and being able to influence decisions that affect the country. He goes further to say that education is the development of human beings in the cognitive, affective and psychomotor domains. Then, [2], sees leadership as the state of being a 
leader or in a position to control. There is a general agreement between educationist and educators that education involves a desirable change in human behaviour, through the process of teaching and learning. This means that a human being who exhibits undesirable character from the point of view of the acceptable societal norms and values cannot be said to be educated [3]. Education is a social service, provided worldwide with multiple objectives in mind [4]. The objectives, according to [5] vary from the acquisition of basic skills required for more rapid growth of the economy and basic knowledge for the individual to function effectively in the society.

\section{Methodology}

The methodology used in this work is both observational and historical methods. The choice of these methods is inform by the fact that, observational technique provides not only the ability to perceive events as they occur, but also to provide the opportunity to nose for fine details that may be taken for granted [1]. The decision is also prompted by the attempt to summarize, systematize and simply discourse on the subject under consideration. In addition, the historical method is also used. The decision is also informed by the need to engage in critical investigation of events, development and movements; with regard to the thrush of this research across time and space in other to evaluate them given the current situation under investigation [6]. It is in this context that the observational and historical approaches are considered to be appropriate to appraise politics of education system in the country.

\section{History of Education in Nigeria}

It is an acknowledged fact that the introduction of education was one of the means used by the colonial masters to plant and establish their interest in Nigeria [7]. Having settled down as "Colonial Masters" in Nigeria, they organised and established schools for their young children in their private quarters and church premises. By and large, some top Nigerians who have opportunity of getting closer to the colonial masters brought their children to join. With time, Nigerians started establishing private schools for their young ones too.

Importance of pre-school education is entrenched in the experience and research which shows clearly without doubt that the early formative years (from birth to six years), is the most crucial in the overall development of a child's personality. According to [8], children should be removed from home at an early age and be looked after by people specially trained in the care of young children. [9], is of the opinion that such children would benefit from the knowledge and professional skills in child development, early education, medicine, and special work. The socio-economically deprived children can thus be availed the opportunity to enjoy the valuable provisions of nursery education. In other words, a child who is deprived of nursery education would be missing the much needed assistance for the balance development during the first five years of life.

\section{Nigerian State Formation and Educational Development}

Nigeria is a multicultural state. As a modern state formation, as obtained throughout Africa, the current Nigeria today is a product of the European colonial adventures [10]. The state formation in the era before colonization in Nigeria coincided with the development of indigenous educational systems which were largely informal in nature. They were however organised to meet the needs of the society. These state formations espoused educational development, aimed at inculcating moral norms and values to young ones for both self and overall development of the society [11].

The discourse on the pre-colonial state formations, particularly in Nigeria, often exclude the Pre-Islamic states such as Hausa and Borno empire, located at the Northern side of the country, which later formed the Sokoto Caliphate. In the pre-colonial times, educational development was closely linked with social development and was in conformity with successive stages of physical and mental upbringing of the child. It was difficult to distinguish between education and productive activities or create a division between manual and mental education because they concurrently go together [12].

The ethno-cultural traditions of the people in this epoch directed the process of formal education such as passing of individual from one age grade to another. Such was also instrumental for the development and specialization of individuals into various professions like hunting, priesthood, blacksmithing, farming etc. This implies that Nigerian ethnic groups as were beyond Africa, demonstrated through informal and formal education, the tradition of general knowledge and communal participation through enculturation. 


\section{British Colonization and Politics of Leadership in Education System in Nigeria}

The colonial masters could not do as their presupposition would have permitted them, they fell back on their indigenous traditional rulers to foster colonization, while limiting their boundaries of operations. This was classically "indirect rule system" but largely referred as divide and rule system by Afro-centric scholars. Colonization destroyed ethnocentric values of the Nigerian ethnic groups and stirred up rivalries that have become an enduring character of Nigeria in the $21^{\text {st }}$ century. [12], posits that colonial manipulations laid the foundation of the current problems in Nigeria. Though, most education was provided by the Christian leaders, illustrating another fact about the colonial experience that is, attack on the indigenous culture. This process of enculturation, proved traumatic for many people. On the other hand, according to [13], the imposition of an alien culture stripped many people of their sense and their religion was suppressed; languages replaced, everything indigenous was treated as inferior, and this attitude was taken to schools. A new religion was introduced into the social system to dispel the old ones as life guiding principles and of course educational system and its leadership. [14], is of the opinion that religious arms of colonialism imposed a dominant pattern which denied the people culture equality. They destroyed indigenous institution and values by perpetuating cultural violence mostly in Southern Nigeria and pagan areas of the North, while allowing intact the religious systems of the North.

The colonial politicisation of educational system, according to [15], later manifested virtually in the politics of independent struggle. Within this period, Nigerian elites crystallised and transformed into ethnicity and religious bigots with respective religious enclaves. The North, in terms of western education and skills refused to accept the 1959 proposal for national independence. Before the national independence, several problems afflicted Nigeria Federation, out of which two were fundamental viz:

- The structural imbalance at the federal level.

- The difference spread in the pattern of western education.

These two problems were the original sources of fears of domination arising out of population, size and employment opportunities within the federation. This constituted a conflict of reward power versus expert power.

Emerging from colonial rule, Nigeria engaged in an overshadowed rationalistic character and was left in a lassitude. Elites could not come to terms to develop an acceptable system of education that will strengthen and unite the country, as well as transform the Nigerian society towards inclusive citizenship. They devised separatist systems of education across the three regions. The government of the western region adopted 6-3-3-2-3 system. That is 6 years primary school, 3 years modern school, 3 years secondary school, 2 years high school and 3 years university education. While East and North region settles with 7-5-2-3 system; 7 years primary school, 5 years secondary school, 2 years high school and 3 years university education.

The inconsistencies were informed by the adoption of the federal constitution in the country in 1954 which granted internal self-government to the 3 regions. The division did not only affect the political sphere, but also regionalised the education system [15]. This continued until 1973, following the report of Simeon Adebo committee of national policy on education. The educational objectives stipulated the following objectives:

1) Inculcating national consciousness and unity.

2) Inculcation of right type of values and attitudes for the individuals and the Nigerian society.

3) The training of the mind in the understanding of the world around.

4) The acquisition of appropriate skills, abilities and competencies, both mental and physical and equipping the individual to live and contribute to the development of the society.

These praiseworthy objectives have not fully been implemented in the education system because primordial and patrimonial politics have been taken at the centre stage of the sector. In an attempt to create an egalitarian posture in the education sector, the federal government adopted the "quota system", federal character and catchment areas principle to dispel the ethno-religious divides and imbalance in the leadership of educational sector [16]. Finally, they compounded the problem of identity consciousness. The system has conferred the problem of integration and enhanced regionalism. This was not different under the military even though they tampered with the federation and ineffectual group identities. They consistently stifled the sector's quest for autonomy and underfunded it. This further enhanced divisive tendencies and made education institutions, especially tertiary institutions follow grounds for ethnic and religious mobilizations in Nigeria.

The military nurtured a cabalistic class structure of intelligences from various academic institutions of learning to promote the in-genuine philosophy and continuous stay in power. This was disorganised by the Nigerian politicians, both governing and non-elites, and school leaders having come to terms to depoliticise education in 
Nigeria. Although, at the national level, according to [17], Nigeria has had several people in the academia manning the prestigious ministerial positions as education ministers, they have achieved less at ensuring that the sector receive best attention it requires to meet the standard of international practices. It is a known fact that structural facilities and human and material resources are inadequate in most educational institutions in Nigeria. That gave birth to going to look for investors to come and invest not only invest on education but other sectors. The education sector has received the highest threats in recent times [12].

\section{Politics and Education in Nigerian Schools}

It is a mere talk to say that education is far from politics [18]. The fact remains that education and politics are inextricably related. The policies adopted by any educational system are essentially drawn by the government in power [19]. He further says that, every government is conscious that to ensure its political, social and economic success, the schools must be involved in the promotion of the interests of the governed. On the other hand, educators need the support of the ruling power, the public and other governmental in order to carry out their functions. [14], posits that no educational system can survive without the financial support and the protection of the government in power. In Nigeria, the educational policies of successive governments have always reflected and often betray the political creed and social views of each government both at state and federal levels [5].

According to [12], education contributes to politics, for education is socialisation, and quite essential, a form of political socialisation. In the university for example, they can claim that in their leadership, that politics is not involved, but the leaders know that they cannot operate without political leaders as well. [17], stresses that university leaders and representatives continuously lobby legislators to get into their system or get their activities approved, and adequately financed. In other to further see the interactions of politics and education at work, it is crucial to examine the pertinent aspects of some ideologies and their interplay with education.

\section{Democracy and Education}

The conduct of education in a democracy is guided by a number of acceptable principles [11]. He says that in a democracy, it is the people themselves who elect government and they should be educated to do so responsibly. Not only must they be trained to think clearly and to distinguish truth from falsehood, but they must also acquire knowledge of the issues on which they are to vote. He further says that man must be educated to be free and to acknowledge that freedom entails the acceptance of restraints. In a democracy according to [17], education does not or should not mould people to a rigid pattern, it should be unique, seeking to draw out and develop the special blend of talents that each person possesses. Education should train the open mind which respects and understands the views of others. Education therefore, according to him should develop the habit of productive cooperation as well as healthy cooperation [3]. A child is encouraged to join students' associations which interests him from which he acquires the talent to give and take the habit of working with others. As an adult, he is then able, hopeful, to contribute to many voluntary associations, be it political parties, unions and professional groups.

[1] [2], say that democracy expects of its educational system and its leadership, the growth of the nations to be equipped to assume responsibilities in political settings. But in order to benefit fully from our political system, we must be aware of its weakness as well as its strengths. The teacher must not conceal the ugly facts of political corruption, moral turpitude, and hypocrisy in high places. At the same time, he must clear how much the system contributes to the realisation of its good life. Nigeria is a democratic nation and the discussion, democracy and education should apply to her. In addition, Nigeria has borrowed some important ideas from socialist ideologies. Although, the nation is not anxious to have a classless society, some states are now nevertheless making determined efforts to make education free at all levels and some have in fact abolished private education.

In the opening paragraph of National Policy on Education (1977), it was stated that education in Nigeria is no more private enterprise as it was in the colonial era, but a huge government venture that has witnessed a serious progressive evolution of government's complete and dynamic interaction and active participation. The federal government of Nigeria has adopted education and its leadership as an instrument par excellence for effective national development.

\section{Approaches to School Leadership}

[1] [2], differentiate between school leadership and school management. They suggested that, leadership is a 
process of influencing the movement towards the targeted goals or desired purposes. It involves inspiring and supporting others towards the achievement of a vision for the school which based on clear personal and professional values. Management is just the implementations of the educational policies. The link between leadership and overall success of a school has been recognised for some time. Indeed, it is nearly a quarter of a century since [20], stated that outstanding leadership has invariably emerged as a key characteristics of outstanding schools. These can no longer be doubt that those seeking qualities in education must ensure its presence and that the development of potential leaders must be given high priority. Since there have been numerous studies looking into the impact of effective school leadership, and evidence from range of sources has highlighted the significant role leaders play in increasing school effectiveness [4].

[21], found that effective school leadership is second only to classroom teaching as a school influence on students' learning. In particular, the head teacher's leadership can be critical in influencing improvement in the school's organisation and the teaching and learning environment. [22], meta-analysis of data and evidence found that it was through their ability to influence the instruction in the school that leaders made the greatest impact. [23], found that leaders play a key role in setting the condition to promote reforms and improvements in teaching and learning, through performance management, removing distractions from staff and focusing on the key organisational priorities.

[21] identified ten strong claims for successful school leadership:

1) Head teachers as main source of school's leadership.

2) Head teachers' value are key components in their success.

3) No model for achieving success, but basic leadership practices.

4) Differences in context affect the nature, direction and peace of leadership actions.

5) Heads contribute to students' learning and achievement through a combination and accumulation of strategies and actions.

6) Heads grow and secure success by laying leadership strategies and actions.

7) Successful leaders distribute leadership progressively.

8) The successful distribution of leadership depends on the government that selects the leaders.

9) Leaders contribute to the enhancement of the school educational as academic qualities.

10) Head teachers reshape the condition of teaching and learning.

Notwithstanding, the above leadership qualities of the school head, there is need for every leader to put their leadership practice into operations in ways that are sensitive to their schools' specifics set of circumstances. [24], warned that policies and practices should not be simply transferred between schools without due consideration of culture and contextual appropriateness, they equally pointed out that a challenge for school leaders is to connect models of leadership, which derive from their schools with stated led constructions of professional leadership.

The politics and educational leadership may also shape the leader's approach to a keyed area, which can be characterised as transformational leadership [8]. This is concerned with the construction of a strong connection between the government and the school leadership, which they believe that it will raise motivation and ability of students to achieve more than expected. There is some tentative evidence that government context may influence some school leaders to take a different approach to the distribution of leadership across their organisation [19].

\section{Issues and Challenges for Leadership in Nigerian Schools}

Several issues and challenges are being faced by leaders of public schools based on the influence and powers of government of that state (Maclaren, 2013). Appointment of school heads are done by the ministry or commission in charge of education in various states. The Minister or Commissioner for education is invariably a politician, who has the interest of his party in mind before doing any appointment. On this note, inappropriate person might be appointed, as such, such management might not be successful.

Religious issues are also being considered in most of the appointment of school heads [15]. In a situation whereby the person in the ministry or commission in charge of the appointment of the school head, in most cases keep considering people of the same faith with him. These have made distinctiveness in the educational system. Distinctiveness is viewed as supporting both academic success and positive actions on teaching and learning. The available evidence does show that students in private schools do better academically. One tangible way 
the private schools demonstrate their distinctiveness is through the school curriculum [14]. However, the extent to which public schools do this is very clear. On students' admission, a green biro signature from a member of house of assembly or upper houses has given unqualified students admission, displacing the chances of qualified students; do to number required for admission that very year.

The issue of quota system equally affects the leadership position in the educational sector as well as admission of students. It was made as a policy in the country that a percentage of every state is reserved either for admission or employment in every institution as one Nigeria. In this case, chances of better persons are being denied the non-indigenes based on the Nigerian quota system. On this note, it is evident that politics and educational leadership goes hand in hand and stand to be inseparable in the country.

\section{Conclusion}

The study concludes that education is imperative for any meaningful development of any country. Politics in the educational sector was based mostly on quota system and godfatherism, which adversely affect the educational leadership of the country, matching it slowly to socio-economic, scientific and technological development. There is no need pointing accusing fingers or shifting blames to educational leaders for poor implementations of educational leadership, but the politicians who mastermind the appointment and influence the education leadership with their political powers. On this note, it is evident clear that politics and educational leadership go hand in hand and stand to be inseparable.

\section{Recommendations}

Some recommendations are made based on the study which include:

1) Politicians should allow the education authorities to select leaders of schools with a stated standard; this will give chance for experts and qualified leaders to take leadership positions in schools.

2) There should proper and adequate funding of the educational sectors, at it will give room for effective implementations of the educational policies.

3) Ministerial appointments on academic matters should be strictly on merit and experiences on areas of specialization; this will help to achieve the goals and objectives of education as the appointee is well grounded on the field of educational management and administration.

4) Quota system and godfather should be kept aside until professionals are filled in supposed positions as leaders in the institutions.

5) Admissions of students to schools should be on merit and not based on green pen syndrome.

\section{References}

[1] Bush, K. (2010) School Leadership and Political Impacts on Nations. 2nd Edition, Routledge, London.

[2] Rodney, W. (2012) School Leadership: Concept and Evidence. International Journal for Leadership in Education, 2, 203-223.

[3] Carr, W. and Hartnet, A. (2015) Education and the Struggle for Democracy. 3rd Edition, Open University Press, London.

[4] Igbanugo, C. (2013) Challenges Education Must Accept. Nigerian Educational Council of Association of Education Students, 2, 1-14.

[5] Ikegbusi (2014) Leadership in Educational Sector and Government Interest. University Press, Ibadan.

[6] Post, W.J. and Vikars, M. (2013) Structure and Conflicts in Nigeria. Heinemann Publishers, London.

[7] Okafor, L.M. (2003) History of Senior Secondary School. Jet Publisher, Onitsha.

[8] Plato (2010) Leadership, Theory and Practise of Politics in Education Sector. 4th Edition, Sage, London.

[9] Grant, P.R. (2012) The Identification of Political Problems in Schools' Leadership: A Case Study Located within the English West Midlands. School Leadership and Management, 26, 269-287.

[10] Olaniyi, O.J. (2013) Foundation of Public Policy Analysis. SUNAI Publishers, Ibadan.

[11] Smith, S.J. (2013) Citizenship and Democracy. Sage Publishers, London.

[12] Falola, T. (2010) Ethnicity in Nigerian Politics. Oxford Publishers, Lagos.

[13] Howson, J.U. (2009) The Growth of Academy Chain: Implications for Leaders of Leadership. Nottingham Press and 
Publishers, England.

[14] Toyo, E. (2009) Federalism and Educational Leadership in Nigeria. Penguin Books, London.

[15] Lenshie, N.E. (2006) Corruption, Democracy and National Development in Nigeria. B.Sc. Project, Department of Political Science, Ahmadu Bello University, Zaria.

[16] Okpuko, O.T. (2010) National Policy on Education Leadership and Management. Tunfel Press, Lagos.

[17] Young, M.C. (2012) The Rise of Democracy. Penguin Books, London.

[18] Maclaren, P.C. (2013) Education and the Politics of Human Resistance. Essex Publishers, New York.

[19] Chapman, C.M. (2006) Impact of Federal Government on Schools. Ofsted Publisher, London.

[20] Beare, H. (2007) Creating an Excellent School. Routledge, London.

[21] Day, C., et al. (2009) The Impact of School Leadership on Pupils' Outcomes: Final Report. University of Nottingham Press, Nottingham.

[22] Robinson, V.M. (2009) School Leadership and Students' Outcome: Identifying What Works and Why: Best Evidence Synthesis. Ministry of Education, New Zealand.

[23] Jensen, B. (2012) Catching up: Learning from the Best School in East Asia. Grattan Institute, Australia.

[24] Dimmock, C. and Walker, A. (2013) Introduction: Justifying a Cross-Cultural Comparative Approach to School Leadership and Management. School Leadership and Management, 20, 137-141. http://dx.doi.org/10.1080/13632430050011380

\section{Warmly welcome your paper submission to OALib Journal!}

- Publication on a daily basis

- 9 subject areas of science, technology and medicine

- Fair and rigorous peer-review system

- Fast publication process

- Article promotion in various social networking sites (LinkedIn, Facebook, Twitter, etc.)

- Widely-targeted and multidisciplinary audience to read your research

Submit Your Paper Online: $\underline{\text { Click Here to Submit }}$

Contact Us: service@oalib.com 